\title{
Chromium Speciation Using an Aminated Amberlite XAD-4 Resin Column Combined with Microsample Injection-Flame Atomic Absorption Spectrometry
}

\author{
Erkan Aksoy, ${ }^{1}$ Şükrü Gökhan Elçi, ${ }^{1}$ Ali N. Siyal ${ }^{2}$ and Latif Elçi ${ }^{1, *}$ \\ ${ }^{1}$ Chemistry Department, Faculty of Science and Arts, University of Pamukkale, 20020, Denizli, Turkey \\ ${ }^{2}$ Institute of Advance Research Studies in Chemical Science, University of Sindh, Jamshoro, Pakistan \\ *Corresponding author: E-mail: elçi@pau.edu.tr
}

Received: 10-11-2017

\begin{abstract}
Amberlite XAD-4 resin (AXAD-4) was chemically modified to an aminated Amberlite XAD-4 (AAXAD-4) resin and characterized by infrared spectroscopy. AAXAD-4 resin was used as an efficient solid phase for the preconcentration and speciation of $\mathrm{Cr}(\mathrm{III})$ and $\mathrm{Cr}(\mathrm{VI})$ ions by column technique. The concentration of chromium species was determined by microsample injection system-flame atomic absorption spectrometer (MIS-FAAS). Selective retention of $\mathrm{Cr}$ (III) ions was achieved at $\mathrm{pH} 8.0$ and eluted using $1.0 \mathrm{~mL}$ of $3.0 \mathrm{~mol} \mathrm{~L}^{-1} \mathrm{HCl}$ and $1.0 \mathrm{~mL}$ of $2.0 \mathrm{~mol} \mathrm{~L}^{-1} \mathrm{NaOH}$, successively, at the flow rate of $5.0 \mathrm{~mL} \mathrm{~min}^{-1}$. The maximal sorption capacity of AAXAD-4 resin for $\mathrm{Cr}$ (III) ions was found to be $67.0 \mathrm{mg} \mathrm{g}^{-1}$. The limit of detection (LOD) and limit of quantitation (LOQ) for Cr(III) ions were found to be 0.041 and $0.131 \mu \mathrm{g} \mathrm{L}^{-1}$, respectively, with preconcentration factor $(\mathrm{PF})$ of 375 and relative standard deviation (RSD) of $3.75 \%(\mathrm{n}=11)$. The method was validated using certified reference materials (CRMs) and successfully applied to the real samples, spiked with $\mathrm{Cr}$ (III) and $\mathrm{Cr}(\mathrm{VI})$ ions.
\end{abstract}

Keyword: Aminated Amberlite XAD-4 resin; column; solid-phase; chromium speciation; MIS-FAAS

\section{Introduction}

Speciation of chromium is still one of most important long-standing analytical challenges due to its impact on environmental chemistry, ecotoxicology, clinical toxicology and food industry. Among several redox states, chromium exists mostly in the trivalent $\mathrm{Cr}(\mathrm{III})$ and hexavalent $\mathrm{Cr}(\mathrm{VI})$ redox states with contrasting chemical, biological and toxicological properties. While water insoluble $\mathrm{Cr}(\mathrm{III})$ is an essential ion for mammals, water soluble $\mathrm{Cr}(\mathrm{VI})$ is a human carcinogen, mutagen and toxin due to its high oxidation potential and relatively small size. Compounds of $\mathrm{Cr}(\mathrm{VI})$ are 10 to 100 times more toxic than those of $\mathrm{Cr}(\mathrm{III}) .^{1,2}$ $\mathrm{Cr}(\mathrm{III})$ and $\mathrm{Cr}(\mathrm{VI})$ also cause dermatologic allergy during contact. Thus, US EPA and WHO recommend the threshold value for total chromium as $100 \mu \mathrm{g} \mathrm{L}^{-1}$ for drinking water and $50 \mu \mathrm{g} \mathrm{L}^{-1} \mathrm{Cr}(\mathrm{VI})$ as tolerance level, respectively. ${ }^{3,4}$

The toxicity of metals strongly depends on their oxidation states rather than their total concentrations. ${ }^{5}$ Therefore, metallic species have become a prime task for analytical chemists for years. ${ }^{6}$ Various techniques, such as flame atomic absorption spectrometry (FAAS), graphite furnace atomic absorption spectrometry (GF-AAS), inductively coupled plasma mass spectrometry (ICP-MS), inductively coupled plasma atomic emission spectrometry (ICP-AES), inductively coupled plasma optical emission spectrometry (ICP-OES), thermospray flame furnace atomic absorption spectrometry (TS-FF-AAS) and electrothermal atomic absorption spectrometry (ET-AAS), have been routenly used for the determination of total chromium. ${ }^{7}$ Unfortunately these techniques cannot differentiate $\mathrm{Cr}(\mathrm{III})$ from $\mathrm{Cr}(\mathrm{VI})$ ions. For the speciation and preconcentration of chromium species, several methods based on solid-phase extraction (SPE) ${ }^{8-11}$ coprecipitation, ${ }^{12-14}$ cloud point extraction ${ }^{15}$ and liquid phase microextractions ${ }^{16-18}$ have been developed. Among these, SPE has advantages such as easy operation, smallest consumption of toxic solvents, recycling of solid phases and high selectivity. ${ }^{19,20}$ For speciation of chromium species, activated carbon, ${ }^{21}$ silica gel, ${ }^{22}$ sawdust, ${ }^{23}$ chelating resins ${ }^{11-18,23-25}$ and Amberlite XAD resin series have been used as solid phase. ${ }^{25-27}$ Amine group was incorporated on the polymeric matrix of Amberlite XAD-4 resin. This modified resin was used as effective solid phase for SPE speciation and preconcentration of chromium species. 


\section{Experimental}

\section{1. Apparatus}

A Perkin-Elmer flame atomic absorption spectrometer (AAnalyst 200) equipped with a chromium hollow cathode lamp, an air-acetylene flame atomizer and handmade microinjection system was used for chromium determination. The instrumental parameters were established as recommended by manufacturer: wavelength, $357.9 \mathrm{~nm}$; lamp current, $30.0 \mathrm{~mA}$; slit width, $0.7 \mathrm{~nm}$; acetylene flow, $2.0 \mathrm{~L} \mathrm{~min}^{-1}$ and air flow, $17.0 \mathrm{~L} \mathrm{~min}^{-1}$. As reported in the previous study, a $100 \mu \mathrm{L}$ volume (for all sample and standard solutions) was injected manually into a micropipette tip of the microinjection system connected to the nebulizer of FAAS. ${ }^{13}$ The $\mathrm{pH}$ of solution was carefully measured using a digital pH meter (Hanna 211, Germany). ATR-IR spectrometer (UATR Spectrum Two from PerkinElmer) was used for recording ATR spectra. The reverse osmosis system (Human Corp., Seoul, Korea) was used to obtain ultrapure (UP) quality water (resistivity, $\left.18.2 \mathrm{M} \Omega \mathrm{cm}^{-1}\right)$.

\section{2. Reagents and Solutions}

Analytical grade chemicals and UP water were used throughout the study. Stock solutions of $\mathrm{Cr}$ (III) and $\mathrm{Cr}(\mathrm{VI})$ were prepared using high-purity $\mathrm{Cr}\left(\mathrm{NO}_{3}\right)_{3}$. $9 \mathrm{H}_{2} \mathrm{O}$ (Sigma-Aldrich, St. Louis, MO, USA) and $\mathrm{K}_{2} \mathrm{Cr}_{2} \mathrm{O}_{7}$ (Merck, Darmstadt, Germany), respectively. The working and reference solutions were prepared daily by diluting the stock solutions. Amberlite XAD-4 resin was purchased from Alfa Aesar (Germany). The $\mathrm{pH}$ was adjusted using $\mathrm{CH}_{3} \mathrm{COOH} / \mathrm{CH}_{3} \mathrm{COONa}$ buffer to $\mathrm{pH} 3-6$, a solution of equal volume of $1.0 \mathrm{~mol} \mathrm{~L}^{-1} \mathrm{HCl}$ and $1.0 \mathrm{~mol} \mathrm{~L}^{-1}$ $\mathrm{NaOH}$ solutions for $\mathrm{pH} 7$ and $\mathrm{NH}_{4} \mathrm{NO}_{3} / \mathrm{NH}_{3}$ buffer for pH 7.5-10.

\section{3. Sampling}

The bottled drinking and mineral water samples were purchased from a local market in Denizli, Turkey. The waste water samples were collected from outlet of the wastewater treatment plant in Denizli, Turkey. The fountain water was taken from Incilipınar, Denizli, Turkey. The waste water samples were immediately transported to the laboratory and filtered with $0.45 \mu \mathrm{m}$ cellulose nitrate membrane (Sartorius, GmbH, Germany) under vacuum to remove suspended materials and then analysed by the proposed procedure within $24 \mathrm{~h}$.

\section{4. Chemical Modification of Amberlite XAD-4 resin}

Amberlite XAD-4 resin (polystyrene divinyl benzene) was chemically modified by the reported procedure. ${ }^{26,27} 5.0 \mathrm{~g}$ of Amberlite XAD-4 resin was put into 250
$\mathrm{mL}$ round bottom flask and a nitrating mixture of $10 \mathrm{~mL}$ of concentrated $\mathrm{HNO}_{3}$ and $25 \mathrm{~mL}$ of concentrated $\mathrm{H}_{2} \mathrm{SO}_{4}$ was added. The system was stirred for $1 \mathrm{~h}$ at $60^{\circ} \mathrm{C}$. Reaction mixture was poured into an ice-cold water and filtered. The nitro derivative was washed repeatedly with cold water until acid was rinsed out and air-dried. The nitro group was reduced to amino derivative by refluxing with $40 \mathrm{~g}$ of $\mathrm{SnCl}_{2}$ and $60 \mathrm{~mL}$ of $2.0 \mathrm{~mol} \mathrm{~L}^{-1} \mathrm{HCl}$ in $100 \mathrm{~mL}$ of ethanol. The amino product (AAXAD-4) was treated thoroughly with $2.0 \mathrm{~mol} \mathrm{~L}^{-1}$ sodium hydroxide to decompose the tin-amine complex, followed by $1.0 \mathrm{~mol} \mathrm{~L}^{-1} \mathrm{HCl}$ in order to remove the excess stannous chloride. Finally, the product was washed with excess water and dried at $75^{\circ} \mathrm{C}$ in drying oven for $24 \mathrm{~h}$. The final resin product was confirmed by infrared spectroscopy.

\section{5. Preparation of SPE Column}

A purchased empty Chromabond column SPE cartridge tube ( $3 \mathrm{~mL}$ ) from Macherey-Nagel, Düren, Germany, was packed with $185 \mathrm{mg}$ of aminated resin (ground). Glass wool was used to pack both ends of the column to avoid the loss of the resin during experiments. The flow rate of the sample solution was controlled with Chromabond vacuum manifold. The SPE column was decontaminated by washing with acetone, $1.0 \mathrm{~mol} \mathrm{~L}^{-1} \mathrm{HCl}, 1.0 \mathrm{~mol}$ $\mathrm{L}^{-1} \mathrm{NaOH}$ and water, respectively. For adjusting $\mathrm{pH}$ of the resin to $8, \mathrm{NH}_{4} \mathrm{NO}_{3} / \mathrm{NH}_{3}$ buffer was passed through the column.

\section{6. Speciation and Preconcentration Procedure}

The model solutions in the range of $10-750 \mathrm{~mL}$ including 5-10 $\mu \mathrm{g} \mathrm{Cr}(\mathrm{III})$ or $\mathrm{Cr}(\mathrm{VI})$ were adjusted to $\mathrm{pH} 8$ and passed through the column. $\mathrm{Cr}$ (III) ions were retained on the resin and $\mathrm{Cr}(\mathrm{VI})$ ions were passed as effluent. $\mathrm{Cr}$ (III) ions were eluted by sequential use of $1.0 \mathrm{~mL}$ of 3.0 $\mathrm{mol} \mathrm{L}-1 \mathrm{HCl}$ and $1.0 \mathrm{~mL}$ of $2.0 \mathrm{~mol} \mathrm{~L}^{-1} \mathrm{NaOH}$ at the flow rate of $5.0 \mathrm{~mL} \mathrm{~min}{ }^{-1}$. The $\mathrm{Cr}$ (III) ions in the eluent were determined by MIS-FAAS. The recovery of $\mathrm{Cr}$ (III) ions was quantitatively achieved. The total concentration of chromium was determined by the same procedure after the reduction of $\mathrm{Cr}(\mathrm{VI})$ to $\mathrm{Cr}(\mathrm{III})$ ions using reported reducing mixture of $0.5 \mathrm{~mL}$ of ethanol and $0.5 \mathrm{~mL}$ of concentrated $\mathrm{H}_{2} \mathrm{SO}_{4} \cdot{ }^{29}$

\section{Results and Discussion}

\section{1. Characterization}

The modification of Amberlite XAD-4 resins was characterized by infrared spectroscopy. In supporting information, ATR-IR spectra of unmodified Amberlite XAD-4 resin (Figure S1), nitro derivative (Figure S2) and amino derivative (Figure S3) are given. By comparing 
spectra (Figure S1 and S2), the additional strong peaks in Figure S1 spectrum at 1525 and $1347 \mathrm{~cm}^{-1}$, respectively, correspond to the asymmetric and symmetric stretching vibrations of $\mathrm{N}=\mathrm{O}$ bond in nitro derivative. ${ }^{28}$ By comparing spectra in Figure S2 and Figure S3, appearance of two characteristic peaks at 3359 and $3217 \mathrm{~cm}^{-1}$ in Figure S3 spectrum corresponds to $\mathrm{N}-\mathrm{H}$ bond in amino derivative (primary amine). The spectral information revealed that Amberlite XAD-4 resin was successfully converted to amino derivative.

\section{2. Effect of $\mathbf{p H}$}

The $\mathrm{pH}$ is an important parameter that strongly influences the retention of metal species on the surface of the resin. Thus, the effect of $\mathrm{pH}$ between 2 and 9 on the adsorption of $\mathrm{Cr}(\mathrm{III})$ and $\mathrm{Cr}(\mathrm{VI})$ ions was studied separately. For optimization, $50 \mathrm{~mL}$ of model solutions at $\mathrm{pH}$ from 2 to 9 was passed through the column individually. The adsorbed $\mathrm{Cr}(\mathrm{III})$ and $\mathrm{Cr}(\mathrm{VI})$ ions were eluted by sequential use of $2.5 \mathrm{~mL}$ of $3.0 \mathrm{~mol} \mathrm{~L}^{-1}$ of $\mathrm{HCl}$ and $2.5 \mathrm{~mL}$ of $2.0 \mathrm{~mol} \mathrm{~L}^{-1}$ of $\mathrm{NaOH}$ and determined by MIS-FAAS. At $\mathrm{pH}$

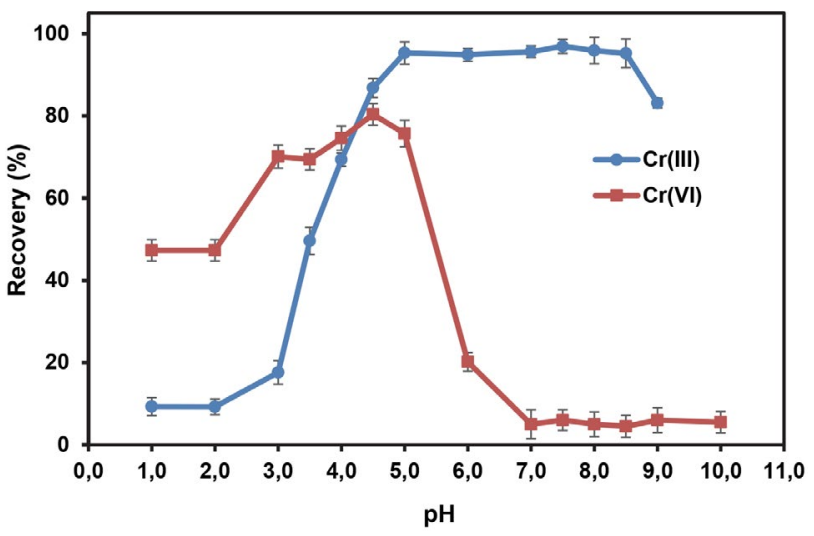

Figure 1. Effect of $\mathrm{pH}$ on recoveries of $1.0 \mu \mathrm{g} \mathrm{L}^{-1} \mathrm{Cr}(\mathrm{III})$ and $1.0 \mu \mathrm{g}$ $\mathrm{L}^{-1} \mathrm{Cr}(\mathrm{VI})$ ions from $50 \mathrm{~mL}$ sample solution $(\mathrm{n}=3)$.
7 through 9, the recoveries of $\mathrm{Cr}(\mathrm{III})$ and $\mathrm{Cr}(\mathrm{VI})$ ions were $\geq 95 \%$ and $\leq 10 \%$, respectively, as shown in Figure 1 . Therefore, $\mathrm{pH} 8$ was selected as the best point for the separation of $\mathrm{Cr}(\mathrm{III})$ and $\mathrm{Cr}(\mathrm{VI})$ ions. Very low uptake of $\mathrm{Cr}(\mathrm{VI})$ ions at $\mathrm{pH} 7$ through 10 can be explained as amino group of AAXAD-4 resin became negatively charged in alkaline medium and possessed electrostatic repulsion with $\mathrm{CrO}_{4}{ }^{2-}$ ions that caused a decrease in the uptake of $\mathrm{Cr}(\mathrm{VI})$ ions. At low $\mathrm{pH}$ values, $\mathrm{Cr}(\mathrm{III})$ exists as its kinetically non-reactive aqua-complex $\mathrm{Cr}\left(\mathrm{H}_{2} \mathrm{O}\right)_{3}{ }^{3+}$ that leads to its low uptake due to possible electrostatic repulsion between $\mathrm{Cr}\left(\mathrm{H}_{2} \mathrm{O}\right)_{3}{ }^{3+}$ and protonated amino group of AAXAD-4 resin. As $\mathrm{pH}$ was increasing, the coordinated water molecules were replaced by the more reactive hydroxide ions, transforming the former complex $\left(\mathrm{Cr}\left(\mathrm{H}_{2} \mathrm{O}\right)_{3}{ }^{3+}\right)$ to a more active form $\left(\mathrm{Cr}\left(\mathrm{H}_{2} \mathrm{O}\right)_{2}(\mathrm{OH})^{2+}\right.$ or $\left.\mathrm{Cr}\left(\mathrm{H}_{2} \mathrm{O}\right)(\mathrm{OH})_{2}^{+}\right)$, which leads to comparatively better interaction with amino group $\left(-\mathrm{NH}_{2}\right)$ of AAXAD-4 resin. ${ }^{31}$

\section{3. Effect of Eluents}

The effects of type, volume and concentration of eluents were tested for the quantitative desorption of $\mathrm{Cr}$ (III) ions from the column. Figure 1 clearly indicates the percentage decrease in recoveries below $\mathrm{pH} 3$ for the uptakes of $\mathrm{Cr}$ (III) ions by AAXAD-4 resin. Thus, $5.0 \mathrm{~mL}$ of $\mathrm{HCl}$ with concentration range from 1.0 through $7.0 \mathrm{~mol} \mathrm{~L}^{-1}$ was tested to elute the $\mathrm{Cr}$ (III) ions. The recovery of $\mathrm{Cr}$ (III) was not achieved quantitavely up to $7.0 \mathrm{~mol} \mathrm{~L}^{-1} \mathrm{HCl}$ as shown in Table 1. At $\mathrm{pH}>8.5$ (Figure 1) the uptake of $\mathrm{Cr}(\mathrm{III})$ ions decreased due to the conversion of $\mathrm{Cr}(\mathrm{OH})_{3}$ to highly soluble tetrahydroxo complex $\left(\mathrm{Cr}(\mathrm{OH})_{4}^{-}\right)$. Thus, $5.0 \mathrm{~mL}$ of $\mathrm{NaOH}$ with concentration range from 1.0 through $4.0 \mathrm{~mol} \mathrm{~L}^{-1}$ was tested to elute the $\mathrm{Cr}(\mathrm{III})$ ions. The quantitative recovery of $\mathrm{Cr}$ (III) ions was not achieved until up to $4.0 \mathrm{~mol} \mathrm{~L}^{-1} \mathrm{NaOH}$ (Table 1). Based on these results, a consecutive use of $2.5 \mathrm{~mL}$ of $3.0 \mathrm{~mol} \mathrm{~L}^{-1} \mathrm{HCl}$ and $2.5 \mathrm{~mL}$ of $2.0 \mathrm{~mol} \mathrm{~L}^{-1} \mathrm{NaOH}$ solutions was tested for desorption of $\mathrm{Cr}(\mathrm{III})$ ions and resulted in quantitative recov-

Table 1. Effect of type, concentration and volume of eluents on the recovery of $1.0 \mu \mathrm{g} \mathrm{L}{ }^{-1} \mathrm{Cr}(\mathrm{III})$ ions in $100 \mathrm{~mL}$ sample from the column $(\mathrm{n}=4)$

\begin{tabular}{lc}
\hline Eluents & Recovery \pm RSD, \% \\
\hline $5.0 \mathrm{~mL} 1.0 \mathrm{~mol} \mathrm{~L}^{-1} \mathrm{HCl}$ & $44.7 \pm 0.8$ \\
$5.0 \mathrm{~mL} 3.0 \mathrm{~mol} \mathrm{~L}^{-1} \mathrm{HCl}$ & $51.7 \pm 2.1$ \\
$5.0 \mathrm{~mL} 5.0 \mathrm{~mol} \mathrm{~L}^{-1} \mathrm{HCl}$ & $67.2 \pm 1.0$ \\
$5.0 \mathrm{~mL} 7.0 \mathrm{~mol} \mathrm{~L}^{-1} \mathrm{HCl}$ & $69.1 \pm 1.2$ \\
$5.0 \mathrm{~mL} 1.0 \mathrm{~mol} \mathrm{~L}^{-1} \mathrm{NaOH}$ & $26.2 \pm 1.4$ \\
$5.0 \mathrm{~mL} 2.0 \mathrm{~mol} \mathrm{~L}^{-1} \mathrm{NaOH}$ & $38.4 \pm 1.3$ \\
$5.0 \mathrm{~mL} 4.0 \mathrm{~mol} \mathrm{~L}^{-1} \mathrm{NaOH}$ & $40.2 \pm 1.1$ \\
$2.5 \mathrm{~mL} 3.0 \mathrm{~mol} \mathrm{~L}^{-1} \mathrm{HCl}$ and then $2.5 \mathrm{~mL} 2.0 \mathrm{~mol} \mathrm{~L}^{-1} \mathrm{NaOH}$ & $97.9 \pm 1.2$ \\
$2.0 \mathrm{~mL} 3.0 \mathrm{~mol} \mathrm{~L}^{-1} \mathrm{HCl}$ and then $2.0 \mathrm{~mL} 2.0 \mathrm{~mol} \mathrm{~L}-1 \mathrm{NaOH}$ & $95.1 \pm 1.2$ \\
$1.0 \mathrm{~mL} 3.0 \mathrm{~mol} \mathrm{~L}^{-1} \mathrm{HCl}$ and then $1.0 \mathrm{~mL} 2.0 \mathrm{~mol} \mathrm{~L}^{-1} \mathrm{NaOH}$ & $96.3 \pm 2.1$ \\
$0.5 \mathrm{~mL} 3.0 \mathrm{~mol} \mathrm{~L}^{-1} \mathrm{HCl}$ and then $0.5 \mathrm{~mL} 2.0 \mathrm{~mol} \mathrm{~L}^{-1} \mathrm{NaOH}$ & $78.7 \pm 1.1$ \\
$0.25 \mathrm{~mL} 3.0 \mathrm{~mol} \mathrm{~L}^{-1} \mathrm{HCl}$ and then $0.25 \mathrm{~mL} 2.0 \mathrm{~mol} \mathrm{~L}^{-1} \mathrm{NaOH}$ & $48.5 \pm 1.1$ \\
\hline
\end{tabular}

Aksoy et al.: Chromium Speciation Using an Aminated Amberlite ... 
ery. The volume of eluent solutions was further decreased to $1.0 \mathrm{~mL}$ of $3.0 \mathrm{~mol} \mathrm{~L}^{-1} \mathrm{HCl}$ and $1.0 \mathrm{~mL}$ of $2.0 \mathrm{~mol} \mathrm{~L}^{-1}$ $\mathrm{NaOH}$ (to obtain high preconcentration factor) and resulted in quantitative recovery of $\mathrm{Cr}$ (III) ions (Table 1). Thus, a consecutive use of $1.0 \mathrm{~mL}$ of $3.0 \mathrm{~mol} \mathrm{~L}^{-1} \mathrm{HCl}$ and $1.0 \mathrm{~mL}$ of $2.0 \mathrm{~mol} \mathrm{~L}^{-1} \mathrm{NaOH}$ solutions was selected as the best eluetion solvent for the desorption of $\mathrm{Cr}$ (III) ions in further experiments.

\section{4. Effect of Sample Volume}

Another strategy to concentrate analyte at very low concentration is to increase the volume of sample. Therefore, the effect of sample volume on the retention of $\mathrm{Cr}$ (III) was studied. The recovery of $\mathrm{Cr}(\mathrm{III})$ ion was achieved quantitatively ( $\geq 95 \%$ ) up to the sample volume of $\leq 750 \mathrm{~mL}$ as shown in Figure 2. Thus, the PF was calculated to be 375 as the ratio of maximal sample volume $(750 \mathrm{~mL})$ to minimal eluent volume $(2.0 \mathrm{~mL})$. Considering time factor, the volume of real samples for analysis was fixed to $100 \mathrm{~mL}$.

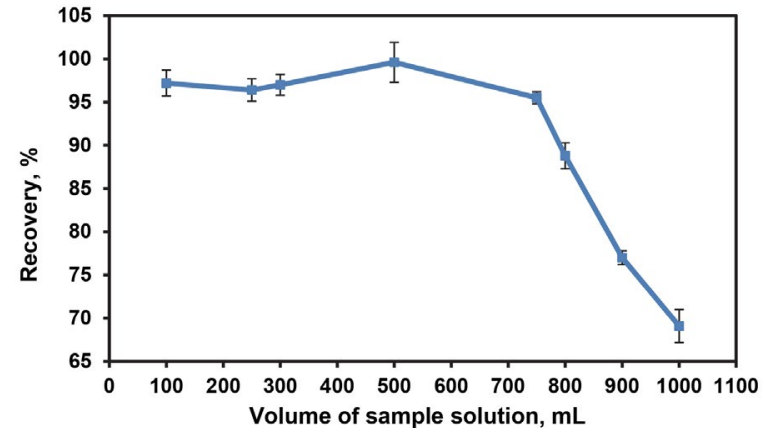

Figure 2. Effect of sample volume on retention of $1.0 \mu \mathrm{g} \mathrm{L}{ }^{-1} \mathrm{Cr}(\mathrm{III})$ ions by the column at $\mathrm{pH} 8(\mathrm{n}=4)$.

\section{5. Effect of Flow Rate of Eluent and Sample Solution}

In order to decrease the preconcentration time, the flow rates of sample and eluent solutions were optimised

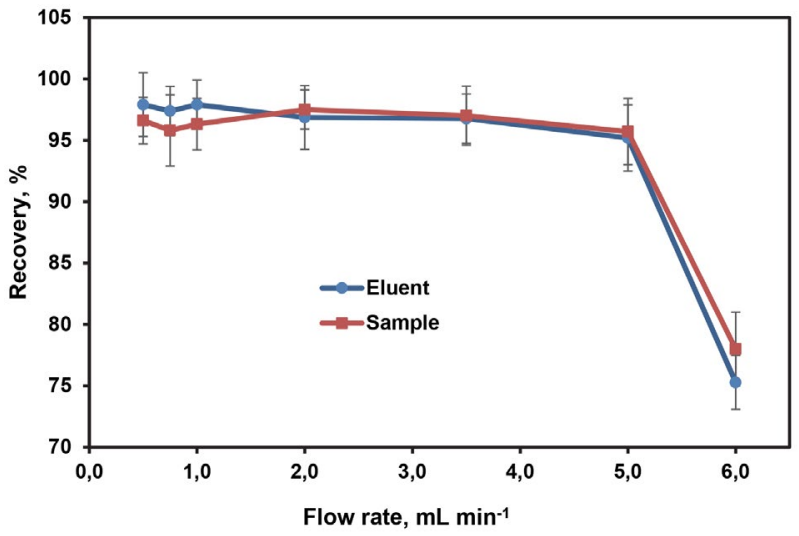

Figure 3. Effect of flow rate of eluent and sample solutions on the recovery of $1.0 \mu \mathrm{g} \mathrm{L}^{-1} \mathrm{Cr}(\mathrm{III})$ ions from $25.0 \mathrm{~mL}$ samples $(\mathrm{n}=4)$. in the range of $0.5-6.0 \mathrm{~mL} \mathrm{~min}-1$. The results (Figure 3) demonstrated that the quantitative retention and percentage recovery of $\mathrm{Cr}(\mathrm{III})$ ions were achieved at the flow rate of $5.0 \mathrm{~mL} \mathrm{~min}{ }^{-1}$ of sample solution and eluent as well.

\section{6. Adsorption Capacity}

The adsorption capacity of the resin is a significant parameter that determines the minimal quantitity of adsorbent required for quantitative uptake of analyte from a sample solution. Based on a previous report in reference $^{31}$, the capacity experiments were conducted. Buffered at $\mathrm{pH} 8.0$ in room temperature, $10 \mathrm{~mL}$ of model solutions containing $\mathrm{Cr}(\mathrm{III})$ in the concentration range of $0.5-400 \mathrm{mg} \mathrm{L}^{-1}$ were equilibrated with $10 \mathrm{mg}$ AAXAD-4 up to $24 \mathrm{~h}$ to saturate amino groups. The adsorption isotherm (Figure 4) was plotted as concentrations of $\mathrm{Cr}$ (III) ions against adsorbed amount of $\mathrm{Cr}(\mathrm{III})$ ions per gram of AAXAD-4 resin. The adsorption capacity of $\mathrm{Cr}(\mathrm{III})$ ions was found to be $67.0 \mathrm{mg} \mathrm{g}^{-1}$ as a value at which the adsorbed amount of $\mathrm{Cr}$ (III) ions remained constant although the concentration of $\mathrm{Cr}$ (III) was increased.

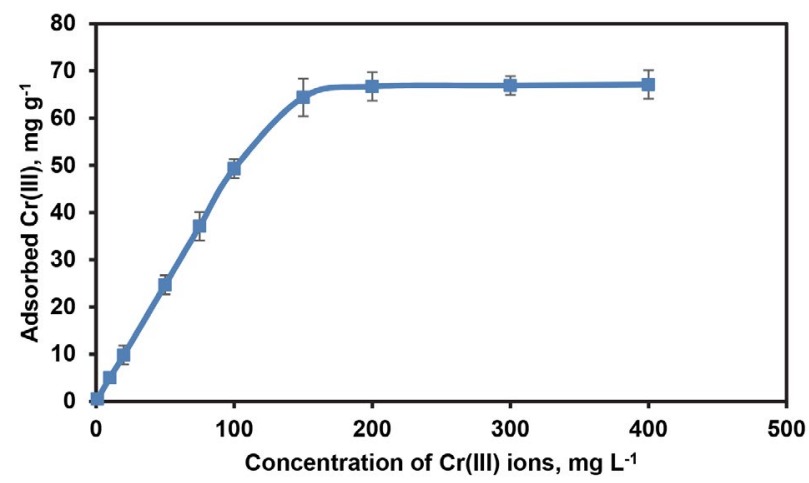

Figure 4. Adsorption isotherm for $\mathrm{Cr}(\mathrm{III})$ ions. Conditions: $10 \mathrm{mg}$ adsorbent, $0.5-400 \mathrm{mg} \mathrm{L}^{-1} \mathrm{Cr}(\mathrm{III})$, Saturation time: $24 \mathrm{~h}$ and $\mathrm{pH}=$ $8.0(\mathrm{n}=3)$.

\section{7. Sorption Competition of Coexisting Ions with $\mathrm{Cr}$ (III) Ions}

Environmental water samples contain many heavy metal ions and some common alkali and alkaline earth metals as coexisting ions. For this reason, the effect of present coexisting ions on the preconcentration of $\mathrm{Cr}(\mathrm{III})$ needs to be evaluated at optimal conditions. For this purpose, $20 \mathrm{~mL}$ of model solution containing $1.0 \mu \mathrm{g} \mathrm{L} \mathrm{L}^{-1}$ of $\mathrm{Cr}$ (III) ions was spiked with possible interfering ions and subjected to the column according to the proposed method. The $\mathrm{Cr}(\mathrm{III})$ ions were quantitatively recovered in the presence of coexisting ions at tolerance limits, taken as a relative error $\leq \pm 5 \%$. It can be seen from Table 2 that the presence of main cations and anions cause an insignificant 
Table 2. The influence of the common coexisting ions on recovery of $1.0 \mu \mathrm{g} \mathrm{L} \mathrm{L}^{-1} \mathrm{Cr}(\mathrm{III})$

\begin{tabular}{|c|c|}
\hline Coexisting ions & $\begin{array}{l}\text { Tolerance limits } \\
\text { of the ions, } \mathrm{mg} \mathrm{L}^{-1}\end{array}$ \\
\hline $\mathrm{Na}^{+} \& \mathrm{~K}^{+}$ & 40000 \\
\hline $\mathrm{Ca}^{2+} \& \mathrm{Mg}^{2+}$ & 250 \\
\hline $\mathrm{CH}_{3} \mathrm{COO}^{-}$ & 8000 \\
\hline $\mathrm{Cl}^{-}$ & 60000 \\
\hline $\mathrm{H}_{2} \mathrm{PO}_{4}^{-}$ & 10000 \\
\hline $\mathrm{SO}_{4}{ }^{2-}$ & 1000 \\
\hline $\mathrm{CO}_{3}{ }^{2-}$ & 3000 \\
\hline $\mathrm{Zn}^{2+}, \mathrm{Ni}^{2+}, \mathrm{Mn}^{2+} \& \mathrm{~Pb}^{2+}$ & 50 \\
\hline $\mathrm{Cu}^{2+}, \mathrm{Hg}^{2+}, \mathrm{Fe}^{2+} \& \mathrm{Fe}^{3+}$ & 10 \\
\hline
\end{tabular}

influence on the retention of $\mathrm{Cr}(\mathrm{III})$ ions onto AAXAD-4 resin. This shows us that AAXAD-4 resin is highly selective for $\mathrm{Cr}$ (III) ions for the analysis of various real water samples.

\section{8. $\mathrm{Cr}$ (III) Determination in Presence of $\mathrm{Cr}(\mathrm{VI})$ and Determination of Total Chromium Amount}

The applicability of the proposed method was tested in presence of $\mathrm{Cr}(\mathrm{VI})$ ions for the determination of $\mathrm{Cr}$ (III) ions. For testing, the synthetic aqueous solutions including various mixtures of $\mathrm{Cr}(\mathrm{III})$ and $\mathrm{Cr}(\mathrm{VI})$ ions at different concentration levels were passed through the column at optimal conditions. $\mathrm{Cr}$ (III) ions were quantitatively separated and retained while $\mathrm{Cr}(\mathrm{VI})$ ions were almost completely passed through the column. This was observed by analyzing the effluent. The recoveries of $\mathrm{Cr}$ (III) ions were achieved quantitatively as shown in Table 3. In further study, the usability of the method for the determination of total chromium amount was also tested. Total chromium was determined after the reduction of $\mathrm{Cr}(\mathrm{VI})$ ions to $\mathrm{Cr}(\mathrm{III})$ ion by adding a mixture of $0.5 \mathrm{~mL}$ of concentrated $\mathrm{H}_{2} \mathrm{SO}_{4}$ and $0.5 \mathrm{~mL}$ of ethanol to $50 \mathrm{~mL}$ of sam- ple solution containing $\mathrm{Cr}(\mathrm{VI})$ and $\mathrm{Cr}(\mathrm{III})$ ions at different concentration levels (Table 3). ${ }^{29}$ The recovery of total chromium was also achieved quantitatively as shown in Table 3.

\section{9. Analytical Performance of the Proposed Method}

The accuracy and validation of proposed method was confirmed by analysing different CRMs such as industrial wastewater (BCR-715), drinking water (TMDW-500) and lyophilised water (BCR-544) for the determination of $\mathrm{Cr}$ (III) ions and total chromium. It was checked by Student's t-test whether the difference between the certified value and the found value was significant. The results shown in Table 4 indicated that there is not a significant difference between certified and found values.

After preconcentration of $\mathrm{Cr}$ (III) ions, the linear equation was $\mathrm{A}=5.5259 \mathrm{X}+0.0008$ and $r^{2}=0.9995$ for $600 \mathrm{~mL}$ with concentration range of $2-12 \mu \mathrm{g} \mathrm{L} \mathrm{L}^{-1}$ of $\mathrm{Cr}$ (III) ions. Before preconcentration, the linear equation was $\mathrm{A}$ $=0.0191 \mathrm{X}+0.0021$ and $r^{2}=0.998$ within the concentration range of $0.2-5.0 \mu \mathrm{g} \mathrm{mL}^{-1}$ of $\mathrm{Cr}(\mathrm{III})$ ions. Theoretical PF was calculated to be 289 as the ratio of slope of linear equation after preconcentration to the slope of linear equation before preconcentration close to the experimental PF of 300, indicating the retention and eluation of the analyte was quantitative with recovery of $96 \%$. The sensitivity was found to be $5.53 \mu \mathrm{g} \mathrm{L}^{-1}$ from the slope of the calibration curve..$^{32}$ The reproducibility of the overall precocentration method in terms of RSD was calculated to be $3.75 \%(\mathrm{n}=11)$ at the concentration of $0.5 \mu \mathrm{g} \mathrm{L} \mathrm{L}^{-1}$ $\mathrm{Cr}(\mathrm{III})$ ions. LOD (blank $+3 \sigma$ ) and LOQ (blank $+10 \sigma$, where $\sigma$ is RSD of blank analysis, $n=20$ ) are defined by IUPAC and were calculated accordingly. 33,34 The LOD and LOQ of $\mathrm{Cr}(\mathrm{III})$ ions were found to be 0.041 and $0.131 \mu \mathrm{g} \mathrm{L}{ }^{-1}$, respectively. AAXAD-4 resin was successfully reused more than 250 times without significant loss in its performance.

Table 3. Test of proposed method for the determination of $1.0 \mu \mathrm{g} \mathrm{L}-1 \mathrm{Cr}(\mathrm{III})$ in presence of $\mathrm{Cr}(\mathrm{VI})$ ions and determination of total chromium (Sample volume: $50 \mathrm{~mL} \& \mathrm{n}=4$ )

\begin{tabular}{|c|c|c|c|c|c|c|c|c|}
\hline \multirow{2}{*}{$\begin{array}{l}\text { Added, } \mu \mathrm{g} \\
\text { Cr(III) }\end{array}$} & \multicolumn{4}{|c|}{ Found, $\mu g$, mean $\pm S D$} & \multicolumn{4}{|c|}{ Recovery,\% } \\
\hline & $\mathrm{Cr}(\mathrm{VI})$ & $\mathrm{Cr}$ & $\operatorname{Cr}(\text { III })^{a}$ & $\mathrm{Cr}(\mathrm{VI})^{\mathrm{b}}$ & $\mathrm{Cr}^{\mathrm{c}}$ & $\mathrm{Cr}(\mathrm{III})$ & $\operatorname{Cr}(\mathrm{VI})$ & $\mathrm{Cr}$ \\
\hline 5 & 5 & 10 & $4.74 \pm 0.5$ & $4.85 \pm 0.06$ & $9.48 \pm 0.16$ & $95 \pm 10$ & $97 \pm 1$ & $95 \pm 2$ \\
\hline 5 & 10 & 15 & $4.79 \pm 0.14$ & $9.86 \pm 0.30$ & $14.28 \pm 0.13$ & $95 \pm 3$ & $99 \pm 3$ & $95 \pm 1$ \\
\hline 5 & 20 & 25 & $5.25 \pm 0.12$ & $19.64 \pm 0.24$ & $24.15 \pm 0.41$ & $105 \pm 2$ & $98 \pm 1$ & $97 \pm 2$ \\
\hline 5 & 30 & 35 & $5.01 \pm 0.06$ & $30.07 \pm 0.37$ & $33.37 \pm 0.34$ & $100 \pm 1$ & $100 \pm 1$ & $95 \pm 1$ \\
\hline 10 & 5 & 15 & $9.40 \pm 0.33$ & $5.05 \pm 0.10$ & $14.49 \pm 0.24$ & $94 \pm 3$ & $101 \pm 2$ & $97 \pm 2$ \\
\hline 20 & 5 & 25 & $18.97 \pm 0.34$ & $4.88 \pm 0.13$ & $23.85 \pm 0.52$ & $95 \pm 2$ & $98 \pm 3$ & $95 \pm 2$ \\
\hline 30 & 5 & 35 & $28.39 \pm 0.68$ & $5.03 \pm 0.10$ & $33.84 \pm 0.84$ & $95 \pm 2$ & $101 \pm 2$ & $97 \pm 2$ \\
\hline
\end{tabular}

$\mathrm{Cr}(\mathrm{III})^{\mathrm{a}}$ : Found amount of $\mathrm{Cr}(\mathrm{III})$ ions in presence of $\mathrm{Cr}(\mathrm{VI})$ ions.

$\mathrm{Cr}(\mathrm{VI})^{\mathrm{b}}$ : Total amount of $\mathrm{Cr}(\mathrm{VI})$ ions by subtracting $\mathrm{Cr}(\mathrm{III})$ amount from total amount of $\mathrm{Cr}$ added.

$\mathrm{Cr}^{\mathrm{c}}$ : Total amount of $\mathrm{Cr}$ determined after reducing $\mathrm{Cr}(\mathrm{VI})$ to $\mathrm{Cr}$ (III) ions in sample solutions 
Table 4. Analysis of some certified reference materials $(\mathrm{n}=3$, final vol.: $2 \mathrm{~mL})$

\begin{tabular}{|c|c|c|c|c|}
\hline & & Certified referen & aterials/sample volu & concentrations \\
\hline & tes & $\begin{array}{c}\text { BCR-715 } \\
\text { industrial waste }\end{array}$ & $\begin{array}{l}\text { CRM TMDW-500 } \\
\text { drinking water/ }\end{array}$ & $\begin{array}{c}\text { BCR-544 } \\
\text { Lyophilised water, }\end{array}$ \\
\hline Total Cr & Certified & $1.00 \pm 0.09$ & $20.0 \pm 0.1$ & $49.6 \pm 1.4^{\mathrm{b}}$ \\
\hline & Found & $1.05 \pm 0.02$ & $19.1 \pm 0.4$ & $47.5 \pm 1.4$ \\
\hline & Recovery,\% & 105 & 95.5 & 95.6 \\
\hline & $t_{\text {test }}$ value & $4.3(\mathrm{~ns})$ & $3.9(\mathrm{~ns})$ & $2.6(\mathrm{~ns})$ \\
\hline $\mathrm{Cr}(\mathrm{III})$ & Certified & - & - & $26.8 \pm 1.0$ \\
\hline & Found & $0.56 \pm 0.02$ & $9.7 \pm 0.1$ & $25.4 \pm 1.1$ \\
\hline & Recovery,\% & - & - & 94.8 \\
\hline & $\mathrm{t}_{\text {test }}$ value & & & $2.2(\mathrm{~ns})$ \\
\hline $\mathrm{Cr}(\mathrm{VI})$ & Certified & - & - & $22.8 \pm 1.0$ \\
\hline & Found & $0.49 \pm 0.02^{\mathrm{a}}$ & $9.4 \pm 0.3^{\mathrm{a}}$ & $22.1 \pm 0.9^{a}$ \\
\hline & Recovery,\% & - & - & 96.9 \\
\hline & $t_{\text {test }}$ value & & & $1.4(\mathrm{~ns})$ \\
\hline
\end{tabular}

${ }^{a}$ Calculated from found total $\mathrm{Cr}$ and $\mathrm{Cr}(\mathrm{III})$ concentrations. ${ }^{\mathrm{b}}$ Calculated from the certified $\mathrm{Cr}(\mathrm{III})$ and $\mathrm{Cr}(\mathrm{VI})$,

${ }^{c}$ Significance of $t$-test $(n=3)$ at $95 \%$ confidence level, $t_{\text {critical }}=4.30$; ns: Not Significant.

\section{10. Application of the Developed Method}

The proposed method was applied successfully on different real water samples for the determination of $\mathrm{Cr}$ (III) ions and total chromium. The samples were analysed before and after spiking with $\operatorname{Cr}($ III) ions and
$\mathrm{Cr}(\mathrm{VI})$ ions. The recoveries of $\mathrm{Cr}(\mathrm{III})$ ions from the samples were achieved quantitatively as shown in Table 5. The total chromium levels of Incilipınar drinking fountain water and outlet water of waste water plant (Denizli, Turkey) samples do not pose a risk for public health.

Table 5. Determination of $\mathrm{Cr}(\mathrm{III})$ and $\mathrm{Cr}(\mathrm{VI})$ in various water samples (sample volume: $100 \mathrm{~mL}, \mathrm{n}=4$ ).

\begin{tabular}{|c|c|c|c|c|c|c|c|}
\hline \multirow[t]{2}{*}{ Samples } & \multicolumn{2}{|c|}{ Added, $\mu \mathrm{g} \mathrm{L}^{-1}$} & \multicolumn{3}{|c|}{ Found, $\mu \mathrm{g} \mathrm{L}^{-1}$} & \multicolumn{2}{|c|}{ Recovery,\% } \\
\hline & $\operatorname{Cr}(\mathrm{III})$ & $\mathrm{Cr}(\mathrm{VI})$ & $\mathrm{Cr}(\mathrm{III})$ & $\mathrm{Cr}(\mathrm{VI})^{\mathrm{a}}$ & Total Cr ${ }^{\mathbf{b}}$ & Cr (III) & $\mathrm{Cr}(\mathrm{VI})$ \\
\hline \multirow{4}{*}{$\begin{array}{l}\text { Nestle bottled } \\
\text { drinking water }\end{array}$} & - & - & n.d. & n.d. & n.d. & - & - \\
\hline & 20 & 20 & $20.72 \pm 0.79$ & $19.29 \pm 2.02$ & $40.01 \pm 1.86$ & $104 \pm 4$ & $96 \pm 10$ \\
\hline & 40 & 20 & $40.81 \pm 1.75$ & $20.31 \pm 1.81$ & $61.12 \pm 0.46$ & $102 \pm 4$ & $102 \pm 9$ \\
\hline & 20 & 40 & $21.18 \pm 1.39$ & $38.11 \pm 1.74$ & $58.29 \pm 1.05$ & $106 \pm 7$ & $93 \pm 4$ \\
\hline \multirow{4}{*}{$\begin{array}{l}\text { Pure bottled } \\
\text { drinking water }\end{array}$} & - & - & n.d. & n.d. & n.d. & - & - \\
\hline & 20 & 20 & $19.10 \pm 0.22$ & $20.59 \pm 1.14$ & $39.69 \pm 1.12$ & $96 \pm 1$ & $103 \pm 6$ \\
\hline & 40 & 20 & $39.36 \pm 1.21$ & $20.49 \pm 1.42$ & $59.85 \pm 0.76$ & $98 \pm 3$ & $102 \pm 7$ \\
\hline & 20 & 40 & $19.55 \pm 0.76$ & $39.74 \pm 1.20$ & $59.29 \pm 0.93$ & $98 \pm 4$ & $99 \pm 3$ \\
\hline \multirow[t]{4}{*}{ Mineral water } & - & - & n.d. & n.d. & n.d. & - & - \\
\hline & 40 & 40 & $42.13 \pm 1.99$ & $37.21 \pm 3.29$ & $79.34 \pm 4.90$ & $105 \pm 5$ & $93 \pm 8$ \\
\hline & 80 & 40 & $79.48 \pm 2.66$ & $41.22 \pm 3.24$ & $120.70 \pm 3.05$ & $99 \pm 3$ & $103 \pm 8$ \\
\hline & 40 & 80 & $41.40 \pm 0.31$ & $78.45 \pm 4.58$ & $119.85 \pm 4.57$ & $104 \pm 1$ & $98 \pm 6$ \\
\hline \multirow{4}{*}{$\begin{array}{l}\text { İncilipınar } \\
\text { drinking } \\
\text { fountain water }\end{array}$} & - & - & $1.14 \pm 0.07$ & $0.79 \pm 0.11$ & $1.93 \pm 0.08$ & - & - \\
\hline & 20 & 20 & $21.22 \pm 0.63$ & $19.69 \pm 1.11$ & $40.91 \pm 0.91$ & $106 \pm 3$ & $98 \pm 6$ \\
\hline & 40 & 20 & $41.11 \pm 1.39$ & $19.89 \pm 1.74$ & $61.00 \pm 1.05$ & $103 \pm 4$ & $99 \pm 9$ \\
\hline & 20 & 40 & $20.91 \pm 1.00$ & $40.26 \pm 1.44$ & $61.17 \pm 1.04$ & $105 \pm 5$ & $101 \pm 3$ \\
\hline \multirow{4}{*}{$\begin{array}{l}\text { Outlet water } \\
\text { of waste water } \\
\text { plant (Denizli) }\end{array}$} & - & - & $6.45 \pm 0.12$ & $1.22 \pm 0.54$ & $7.67 \pm 0.53$ & - & - \\
\hline & 20 & 20 & $19.60 \pm 0.65$ & $21.26 \pm 1.08$ & $40.86 \pm 0.86$ & $98 \pm 3$ & $106 \pm 5$ \\
\hline & 40 & 20 & $40.90 \pm 0.97$ & $20.25 \pm 1.58$ & $61.15 \pm 1.25$ & $102 \pm 2$ & $101 \pm 8$ \\
\hline & 20 & 40 & $20.02 \pm 0.87$ & $41.10 \pm 1.26$ & $61.12 \pm 0.91$ & $101 \pm 4$ & $103 \pm 3$ \\
\hline
\end{tabular}

${ }^{\text {a }}$ Calculated from found total $\mathrm{Cr}$ and $\mathrm{Cr}$ (III) concentrations.

${ }^{\mathrm{b}}$ Total amount of $\mathrm{Cr}$ determined after reducing $\mathrm{Cr}(\mathrm{VI})$ to $\mathrm{Cr}$ (III) ions in sample solutions 


\subsection{Comparison}

Analytical performance of the proposed method was compared with recently reported methods. In comparsion, LOD and PF of reported method are better than those of reported methods shown in Table 6.

\section{Conclusion}

In this work, a modified AAXAD-4 resin column was evaluated for the speciation of $\mathrm{Cr}$ (III) and $\mathrm{Cr}$ (VI) ions, providing for selective preconcentration of $\mathrm{Cr}$ (III) at high $\mathrm{pH}$. Besides its good selectivity between $\mathrm{Cr}$ (III) and $\mathrm{Cr}(\mathrm{VI})$ ions, it also has some characteristics such as good stability under working conditions, fast sorption and desorption kinetics, large adsorption capacity and good tolerance to coexisting ions. The used SPE system could recover more than $95 \%$ of $\mathrm{Cr}$ (III) from aqueous solution at $\mathrm{pH}=8$. The feasibility of speciation at $\mu \mathrm{g} \mathrm{L}^{-1}$ levels make it an efficient sorbent for $\mathrm{Cr}$ (III). By com- bining AAXAD-4 minicolumn SPE with MIS-FAAS, the developed method was successfully applied for chromium speciation in various water samples with low LOD, high PF, good accuracy and repeatability. Because of its simplicity, low cost and safety, it could be adopted for routine use for the speciation of $\mathrm{Cr}$ (III) and $\mathrm{Cr}(\mathrm{VI})$ ions.

\section{Conflict of Interest}

Authors declare that they do not have any conflict of interest with anyone.

\section{Acknowledgement}

The authors would like to acknowledge the scientifical research projects unit of Pamukkale University which is the fund to this study (No. 2014 FEF 011).

Table 6. Comparison of proposed method with reported methods for speciation of $\mathrm{Cr}(\mathrm{III})$ and $\mathrm{Cr}$ (VI) ions based on SPE

\begin{tabular}{|c|c|c|c|c|c|c|}
\hline Resins/Techniques & $\begin{array}{l}\text { Speciation } \\
\text { Modality }\end{array}$ & $\begin{array}{l}\text { Sample } \\
V, \mathbf{m L}\end{array}$ & $\begin{array}{l}\text { LOD, } \\
\mu g L^{-1}\end{array}$ & $\mathbf{P F}$ & $\begin{array}{l}\text { RSD, } \\
\%\end{array}$ & $\begin{array}{c}\text { Refs } \\
\#\end{array}$ \\
\hline $\begin{array}{l}\text { Amberlite XAD-16 loaded } \\
\text { with salicylic acid/on-line column }\end{array}$ & $\begin{array}{l}\mathrm{Cr}(\mathrm{III}) \text { sorption/ } \\
\mathrm{Cr}(\mathrm{VI}) \text { reduction }\end{array}$ & 10 & 0.10 & 79 & 1.2 & 11 \\
\hline $\begin{array}{l}\text { Silica gel modified by } N, N^{\prime} \text {-bis- } \\
\text { ( } \alpha \text {-methyl salicylidene)-2,2-dimethyl- } \\
\text { 1,3-propa- nediimine/ column }\end{array}$ & $\begin{array}{l}\text { Cr(III) sorption/ } \\
\text { Total Cr By GFAAS }\end{array}$ & $\begin{array}{c}0.024 \\
500\end{array}$ & 50 & 3.1 & 22 & \\
\hline $\begin{array}{l}\text { Amberlite XAD- } 16 \text { modified with } \\
\text { a-benzoin oxime/on-line column }\end{array}$ & $\begin{array}{l}\mathrm{Cr}(\mathrm{III}) \text { sorption/ } \\
\mathrm{Cr}(\mathrm{VI}) \text { reduction }\end{array}$ & 10 & 0.14 & 76 & 1.03 & 24 \\
\hline $\begin{array}{l}\text { Maleic acid-functionalized } \\
\text { XAD sorbent/column } \\
\mathrm{Cr}(\mathrm{VI}) \text { reduction } \mathrm{C}-18 \text { bonded } \\
\text { phase silica/ SPE disks }\end{array}$ & $\begin{array}{l}\mathrm{Cr}(\mathrm{III}) \text { sorption/ } \\
\mathrm{Cr}(\mathrm{VI}) \text { reduction/ } \\
\mathrm{Cr}(\mathrm{VI}) \text { sorption/ } \\
\text { Cr(III) oxidation }\end{array}$ & 6000 & 150 & $\begin{array}{l}300 \\
150\end{array}$ & $\begin{array}{l}0.2 \\
11.2\end{array}$ & 36 \\
\hline $\begin{array}{l}\text { Dowex M } 4195 \\
\text { chelating resin/column }\end{array}$ & $\begin{array}{l}\mathrm{Cr}(\mathrm{VI}) \text { sorption/ } \\
\mathrm{Cr}(\mathrm{III}) \text { oxidation }\end{array}$ & 250 & 1.94 & 31 & $<10$ & 37 \\
\hline $\begin{array}{l}\text { MWCNTs-D2EHPA/ } \\
\text { batch }\end{array}$ & $\begin{array}{l}\mathrm{Cr}(\mathrm{III}) \text { sorption } \\
\mathrm{Cr}(\mathrm{VI}) \text { reduction }\end{array}$ & 300 & 50 & 60 & $<10$ & 38 \\
\hline $\begin{array}{l}\text { (MAD) chelating } \\
\text { resin/column }\end{array}$ & $\begin{array}{l}\mathrm{Cr}(\mathrm{III}) \text { sorption/ } \\
\mathrm{Cr}(\mathrm{VI}) \text { reduction }\end{array}$ & 2000 & 0.01 & 200 & 1.2 & 39 \\
\hline $\begin{array}{l}\text { Poly(1,3-thiazol-2-yl- } \\
\text { methacrylamide)-co-4-vinyl } \\
\text { pyridine-co-divinyl benzene / } \\
\text { column }\end{array}$ & $\begin{array}{l}\mathrm{Cr}(\mathrm{VI}) \text { sorption/ } \\
\mathrm{Cr}(\mathrm{III}) \text { oxidation }\end{array}$ & 150 & 2.4 & 30 & 3.2 & 40 \\
\hline $\begin{array}{l}\text { Chromium(III)-cochineal } \\
\text { red A chelate/filter } \\
\text { Diphenylcarbazone-incorporated } \\
\text { resin/column }\end{array}$ & $\begin{array}{l}\mathrm{Cr}(\mathrm{III}) \text { sorption/ } \\
\mathrm{Cr}(\mathrm{VI}) \text { reduction } \\
\mathrm{Cr}(\mathrm{III}) \text { sorption/ } \\
\text { Total Cr by GFAAS }\end{array}$ & $\begin{array}{l}800 \\
-\end{array}$ & $\begin{array}{l}1.4 \\
30\end{array}$ & $\begin{array}{l}94 \\
-\end{array}$ & $\begin{array}{c}<5 \\
3.2-3.7\end{array}$ & $\begin{array}{l}41 \\
42\end{array}$ \\
\hline $\begin{array}{l}\text { Aminated XAD- } 4 \text { / } \\
\text { column }\end{array}$ & $\begin{array}{l}\mathrm{Cr}(\mathrm{III}) \text { sorption/ } \\
\mathrm{Cr}(\mathrm{VI}) \text { reduction }\end{array}$ & 750 & 0.041 & 375 & 3.75 & This work \\
\hline
\end{tabular}




\section{References}

1. J. Namiesnik, A. Rabajczyk. Crit. Rev. Environ. Sci. Technol., 2012, 42, 327-377. DOI:10.1080/10643389.2010.518517

2. J. O. Nriagu, E. Nieboer (Eds.), Chromium in the Natural and Human Environment, Wiley, New York, 1998.

3. US EPA. Report No. EPA/570/9-76/003; Washington, DC, 1976.

4. Code of Federal Regulation. Protection of Environment. Section 141, 80, p. 425, 2011.

5. P. Quevauviller, E. A. Maier, B. Griepink, Fresenius J. Anal. Chem., 1993, 3459 (2-4), 282-286.

DOI:10.1007/BF00322611

6. N. Ozdemir, M. Soylak, L. Elci, M. Dogan, Anal. Chim. Acta, 2004, 505(1), 37-41.

DOI:10.1016/S0003-2670(03)00353-2

7. A. N. Siyal, S. Q. Memon, A. Elci, A. Akdogan, A. Hol, A. Arslan Kartal, L. Elci, Int, J. Environ. Anal. Chem., 2014, 94(14-5), 1463-1477.

8. S. Chen, S. Zhu, Y. He, D. Lu. Food Chem., 2014, 150, 254-259. DOI:10.1016/j.foodchem.2013.10.150

9. C. Cui, M. He, B. Chen, B. Hu. Anal. Methods, 2014, 6, 85778583. DOI:10.1039/C4AY01609B

10. S. Tiwari, N. Sharma and R. Saxena. Anal. Sci., 2016, 32, 1321-1325. DOI:10.2116/analsci.32.1321

11. R. Ansari. Acta Chim. Slov., 2006, 53, 88-94.

12. J. A. Baig, L. Elci, M. I. Khan, T. G. Kazi. J. AOAC Int., 2014, 97(5), 1421-1425. DOI:10.5740/jaoacint.12-139

13. J. A. Baig, A. Hol, A. Akdogan, A. Arslan Kartal, U. Divrikli, T. G. Kazi, L. Elci. J. Anal. At. Spectrom., 2012, 27, 1509-1517. DOI:10.1039/c2ja30107e

14. A. Karatepe, E. Korkmaz, M. Soylak, L. Elci. J. Hazard. Mater., 2010, 173(1-3), 433-437.

DOI:10.1016/j.jhazmat.2009.08.098

15. L. Zhang, L. Xuelei, X. Wang, W. Wang, X. Wang, H. Han. Anal. Methods, 2014, 6(15), 5578-5583.

DOI:10.1039/C4AY00922C

16. E. Yilmaz and M. Soylak. Talanta, 2016, 160, 680-685.

DOI:10.1016/j.talanta.2016.08.001

17. S. Kapitány, E. Sóki, J. Posta, Á. Béni. Acta Chim. Slov., 2017, 64, 248-255. DOI:10.17344/acsi.2017.3137

18. Z. Bahadir, V. N. Bulut, M. Hidalgo, M. Soylak, E. Marguí. Spectrochim. Acta B, 2016, 115, 46-51.

DOI:10.1016/j.sab.2015.11.001

19. R. K. Sharma and P. Pant. Int. J. Environ. Anal. Chem., 2009, 89, 503-514. DOI:10.1080/03067310802691680

20. E. Molaakbari, A. Mostafavi, and D. Afzali, Int. J. Environ. Anal. Chem., 2013, 93, 365-376.

DOI:10.1080/03067319.2012.663753

21. R. A. Gil, S. Cerutti, J. A. Gasquez, R. A. Olsina, L. D. Martinez. Talanta, 2006, 68, 1065-1070.

DOI:10.1016/j.talanta.2005.06.069
22. A. Bartyzel and E. M. Cukrowska. Anal. Chim. Acta, 2011, 707, 204-209. DOI:10.1016/j.aca.2011.09.023

23. S. Q. Memon, M. I. Bhanger and M. Y. Khuhawer. Anal. Bioanal. Chem., 2005, 383, 619-624.

DOI:10.1007/s00216-005-3391-1

24. S. Tiwari, N. Sharma and R. Saxena. New J. Chem., 2016, 40(2),1412-1419. DOI:10.1039/C5NJ02283E

25. R. K. Sharma and P. Pant. J. Hazard. Mater., 2009, 163(1), 295-301. DOI:10.1016/j.jhazmat.2008.06.120

26. H. A. Panahi, H. S. Kalal, E. Moniri, M. N. Nezhati, M. T. Menderjani, S. R. Kelahrodi, F. Mahmoudi. Microchem. J., 2009, 93, 49-54. DOI:10.1016/j.microc.2009.04.007

27. I. B. Solangi, S. Memon and M. I. Bhanger. J. Hazard. Mater., 2009, 171, 815-819. DOI:10.1016/j.jhazmat.2009.06.072

28. A. A. Bhatti, S. Memon, N. Memon, A.A. Bhatti, I. B. Solangi. Arab. J. Chem, 2017, 10, S1111-S1118.

DOI:10.1016/j.arabjc.2013.01.020

29. V. N. Bulut, D. Ozdes, O. Bekircan, A. Gundogdu, C. Duran, M. Soylak, Anal. Chim. Acta, 2009, 632, 35-41.

DOI:10.1016/j.aca.2008.10.073

30. D. L. Pavia, G. M. Lampman and G. S. Kriz. Introduction to Spectroscopy, Third Ed., Cengage Learning, 2001.

31. H. Peng, N. Zhang, M. He, B. Chen, B. Hun. Talanta, 2015, 131, 266-272. DOI:10.1016/j.talanta.2014.07.054

32. B. Welz, Atomic Absorption Spectrometry, 2nd ed., VCH, New York, 1985, p. 108.

33. Analytical Methods Committee, Analyst, 1987, 112, 199-204. DOI:10.1039/an9871200199

34. IUPAC, Analytical Chemistry Division, Spectrochim. Acta Part B, 1978, 33, 241-245.

DOI:10.1016/0584-8547(78)80044-5

35. S. Yalcin and R. Apak. Anal. Chim. Acta, 2004, 505, 25-35. DOI:10.1016/S0003-2670(03)00498-7

36. M. S. Tehrani, A. A. Ebrahimi and F. Rastegar. Annali di Chimica, 2004, 94(5-6), 429-435.

DOI:10.1002/adic.200490052

37. K. O. Saygi, M. Tuzen, M. Soylak, L. Elci. J. Hazard. Mater., 2008, 153, 1009-1014. DOI:10.1016/j.jhazmat.2007.09.051

38. S. Vellaichamy and K. Palanivelu. Indian J. Chem., 2010, 49A, 882-890.

39. S. Sacmaci, S. Kartal, Y. Yılmaz, M. Sacmaci, C. Soykan. Chem. Eng. J., 2012 (181-182), 746-753.

DOI:10.1016/j.cej.2011.11.057

40. O. Hazer and D. Demir. Anal. Sci., 2013, 29, 729-734. DOI:10.2116/analsci.29.729

41. M. Habila, Y. E. Unsal, Z. A. Alothman, A. Shabaka, M. Tuzen, M. Soylak. Anal. Lett., 2015, 48(14), 2258-2271.

DOI:10.1080/00032719.2015.1025278

42. B. Lesniewska, A. Jeglikowska, B. Godlewska-Zylkiewicz. Water Air Soil Pollut., 2016, 227, 291.

DOI:10.1007/s11270-016-2974-0 


\section{Povzetek}

S kemično modifikacijo smo Amberlite XAD-4 smolo (AXAD-4) pretvorili v aminirano Amberlite XAD-4 (AAXAD-4) smolo in jo okarakterizirali $\mathrm{z}$ infrardečo spektroskopijo. AAXAD-4 smolo smo uporabili kot učinkovito trdno fazo za predkoncentracijo in speciacijo $\mathrm{Cr}(\mathrm{III})$ in $\mathrm{Cr}(\mathrm{VI})$ ionov s kolonsko tehniko. Koncentracijo kromovih zvrsti smo določili z mikrovzorčevalnim injekcijskim sistemom in plamenskim atomskim absorpcijskim spektrometrom (MIS-FAAS). Selektivno retencijo $\mathrm{Cr}(\mathrm{III})$ ionov smo dosegli pri $\mathrm{pH} 8,0$ in elucijo $\mathrm{z} 1,0 \mathrm{~mL} 3,0 \mathrm{~mol} \mathrm{~L}^{-1} \mathrm{HCl}$ ter $1,0 \mathrm{~mL} \mathrm{2,0} \mathrm{mol} \mathrm{L}^{-1} \mathrm{NaOH}$ zaporedoma pri pretoku 5,0 $\mathrm{mL} \mathrm{min}^{-1}$. Maksimalna sorpcijska kapaciteta AAXAD-4 smole za Cr(III) ione je bila 67,0 mg g $\mathrm{g}^{-1}$. Meja zaznave (LOD) za Cr(III) ione je bila $0,041 \mu \mathrm{g} \mathrm{L}{ }^{-1}$, meja določitve (LOQ) $0,131 \mu \mathrm{g} \mathrm{L}{ }^{-1}$, medtem ko je bil predkoncentracijski faktor (PF) 375 in relativni standardni odmik (RSD) 3,75\% $(n=11)$. Metodo smo validirali s certificiranimi referenčnimi materiali (CRM) in jo uspešno uporabili za analizo realnih vzorcev $\mathrm{z}$ dodanimi $\mathrm{Cr}(\mathrm{III})$ in $\mathrm{Cr}(\mathrm{VI})$ ioni. 